\title{
ICT-Based Business Initiatives for Women: An Outline of Best Practices in E-Commerce/E-Retailing Ventures
}

\author{
Mahadi Hasan Miraz ${ }^{1 *}$, Mamun Habib², Ferdoush Saleheen ${ }^{3}$ \\ ${ }^{1,3}$ School of Quantitative Sciences, Universiti Utara Malaysia, Malaysia \\ ${ }^{2}$ BRAC Business School, BRAC University, Bangladesh \\ Email: ${ }^{1}$ mahadimiraz1@gmail.com, ${ }^{2}$ mamunhabib@bracu.ac.bd, ${ }^{3}$ ferdoushsaleheen@gmail.com
}

\begin{abstract}
The promotion of information and communication technologies (ICTs) has changed dramatically. It is becoming a role for inclusive growth, deficiency eradication and the influence to inspire women and particularly in south Asia. ICT-based commercial enterprises, and e-commerce jobs in particular, have been hailed as "possible successes" for women's development. Though, study and practice show that to be effective, projects must stabilize the need to overcome structural obstacles to women's progress with compassion to the incomplete space within which many women in the Worldwide South Asia. In this article, we evaluate literature on ICT and inspiration of women, drawing upon numerous e-commerce/ e-retailing jobs as case studies to recognize a set of best performances that motivate an effective project: 1) government and institutional support, 2) social contribution, 3) training, 4) growth of market access, and 5) managerial best performances. We anticipate that the insights produced by this study will be valuable both for purposes of in effect program growth and strategy design.
\end{abstract}

Keywords: ICT, woman inspiration, business initiatives, e-commerce/ e-retailing and business performance.

\section{Introduction}

This research is inspired by the potentially powerful role that information and communication technologies (ICTs) can play in the empowerment of women in the poor and underdeveloped societies in the world. [1] In this essay, we review the literature on ICTs and empowerment of women, drawing upon several e-commerce/e-retailing projects as case research to recognize a set of "best practices" that underlie a positive project [2]. We anticipate that the intuitions developed in this research would be beneficial both for purposes of effective program progress and policy design [3]. ICTs are gradually promoted as a key solution for comprehensive development, lack eradication and the empowerment of historically disadvantaged groups, such as women and minorities in the Global South Asia.

\section{Literature Review: ICT Development and Business Initiatives for}

\section{Woman}

Implements for economic development. A study (2005) describes ICTs as potentially powerful "development enablers:" they are cost-effective with significant transformative power, emerging countries to leapfrog several stages of the development process and, in furnishing individuals directly with tools for self-empowerment, avoid top-heavy and dishonest administrations [7]. Specially, [8] argue that ICTs "can enhance the functioning of markets that are critical for the well-being of the poor" because ICTs can foster greater market integration in many ways:

- They allow farms and individuals in emerging countries to contribute more competitively and with better ease in the regional, national and global economies and reduce uncertainty in doing business;

- Information regarding values permits manufacturers to design their product combination and input buying in an efficient way;

Access to ICTs allows creators to trade their products in the most portable markets and decide the finest timing of sale; 
$>$ Accessibility of value information shrinks the informational asymmetry among the rural producers and middlemen;

$>$ ICTs decrease the spreading of rural producers by e-middlemen;

> Enlarged information simplifies expertise distribution, acceptance and invention at a much quicker pace;

$>$ Advance information about the accessibility of jobs could result in improved and quicker similar among landless laborers and available jobs, eventually leading to improved efficiency;

> ICTs deliver larger access to weather-related information and credit opportunities. In short, access to ICT and proper use of this access could place an economy on a higher income by over time.

Powerful "development enablers" and the World Bank currently supports more than 230 jobs with an IT component [4]. At the same time, the Declaration of Agreement in Support Of Girls and Women in Information and Communication Technology, presented at the United Nations World Summit on the Information Society in Tunis. It also exposes that "ICT permits women improved participation in political, social, and economic arenas and supports enablement for themselves, their families, and their communities." Though, it also cautions that "failing to identify and remedy women's severe underrepresentation in the development of ICTs and ICT policy, as well as both access and leadership, limits our ability to advance our worldwide advance development."

In the current decades, consequently, increasing agencies, such as the World Bank, USAID and the Canadian International Development Research Centre (IDRC) have significantly enlarged funding for ICT projects that specially purpose to empower women, such as e-commerce, e-government, business development, and networking projects. Women have progressively proven to be active and eager participants in a great variety of ICT-enabled projects, such as computer training and data entry services, call centers, billing, computer repair work, and e-enabled businesses. E-commerce projects (traditional or otherwise) that tap the facilities of women and exploit their likely have been mostly popular in worldwide markets. The Georgetown-initiated Cottage Industry-Global Market CI-GM Project, Tortas Peru, the India Shop, ElSouk, EthioShop, Women Entrepreneurs and Handicraft Producers in Bhutan, the World Bank-funded Knitting Together Project and the Rupununi Weavers Society are examples of (at least, initially) successful e-commerce projects. Projects like those by the Delhi-based Datamation Foundation, the Information Village Project in Pondicherry, India and the Grameen Phone Project in Bangladesh serve as models of the potential of ICT based projects.

\section{$3 \quad$ Methodology}

The methodology we established for this research is to first review the literature and recognize issues that simplified effective e-commerce/e-retailing ventures and issues that stuck such projects. We then recognize a set of e-commerce case studies that we investigate to comprehend the extent to which the theoretical findings are authenticated by the field knowledges. Through this procedure we are able to recognize a set of best performances that underlie a project that is effective in empowering women. We define best performances as sets of actions, managerial practices, and policies assumed by women-owned e-commerce/ e-retailing businesses that lead to the empowerment of women both working in those industries and those others who regarded it as a role model to emulate. Many of the case studies involved in the paper have been widely deliberated in the literature. We are partial by the obtainability of data since our specific focus is on e-commerce/e-retailing, and we include mainly case studies we found during our literature quest that exactly relate to e-commerce/e-retailing (rather than the general use of ICTs).

\section{Discussion}

\subsection{Innovative Business Imitative Through ICT}

The works on ICT has huge chances and provide for women's empowerment is vibrant and wide ranging. [9] Have argued that IT's have the potential to enhance the traditional gender roles and that the spread of IT-enabled facilities has been hugely beneficial to equally women and men, particularly those who 
have imperfect services or lack of resources to invest in higher education. [10] has called ICTs the "great equalizer", and inventers in the field of gender enhancement through ICTs, both in academe and advocacy, such as [11]; [12] \& [13] have persuasively shown that access to and effective usage of ICTs contributes to women's improvement and capacity building in many ways, frequently with synergetic effects:

$>$ Training in the use and design of computer applications, such as e-mail, word-processing and design applications, builds in demand services;

$>$ Marketable skills generate substitute potentials for income generation and the likelihood of upward mobility;

$>$ An independent income is the basis for specific independence, better agency and control and, often, improved self- confidence [14].

\section{$4.2 \quad$ E-Commerce / E-Retailing Projects}

$>$ Increased agency and self-confidence allow women to travel more and develop a wider network of contacts. Such travel and networking expose them to the availability of more commercial chances $[15] ;[16]$

$>$ ICTs exposed new roads for learning, communication and info distribution;

$>$ ICTs can be a valued tool for the group and deployment of women's backing and attention [2]; [17].

$>\quad$ Learning and information upturn data about the world and the political, economic, social and social factors that shape women's lives. Finally, women's enabling and a nation's level of economic growth are inextricably interrelated [18].

\subsection{Business Challenges}

There are two important business issues faced by women running micro (e-commerce/e-retailing) enterprises: the finding of necessary loans for seed money and to ensure consistent funding for an existing project, and the resistance to women's empowerment by (male) government officials and fellow villagers [19];[20]. Furthermore, women are faced with the challenge to organize different financial resources. Though in many emerging countries they are incompetent to travel on their own to various distant workplaces and organizations.

\subsection{Societal Challenges}

Women are frequently dispirited, both at the family and country side levels, in their business efforts. Often the fear that it may alternate or shift the power structure creates hurdles in their path. Many women are also indeterminate about their expert chances once they get married. In addition, juggling household responsibilities and work responsibilities can be very challenging and may result in women opting out of the ICT-driven growing efforts [21]. These structural limitations are very difficult to overcome because they are in cultural terms and religiously justified forms of gender discrimination and have been internationalized by men and women alike, permeating all institutions of society.

\subsection{Woman's Initiatives: Challenges and Opportunities}

A research shows that UNCTAD report on E-Commerce and Development hailed e-commerce as a "potential goldmine" for women in the emerging countries because of its great potential for women's empowerment. Women-owned or women-operated telecasters in Senegal and Morocco, telephone shops in Ghana, Internet cafés in Thailand and Malaysia, and the Grameen Phone Project in Bangladesh were cited as examples of how women in developing countries can effectively achieve by new technologies. Accordingly, the interest of development agencies, scholars and activists in e-commerce projects has increased expressively over the six years. As an outcome, the literature on e-commerce is huge, and the overwhelming common of scholars, activists and policymakers agree on the great potential of e-business for women's empowerment, mainly in emerging countries [22]. 


\section{$5 \quad$ E-Commerce and Retailing in Business}

At the same time, the literature is characterized by a definite emphasis on e-commerce in OECD countries, business models especially regarding successful uses of ICTs by women-owned businesses, are based on anecdotal evidence and a few case studies but not on any systematic statistical evidence [23]. The developing countries, compared with $75 \%$ of OECD countries, have collected data on barriers to ecommerce or less countries (and about the same amount of their population) collected data on the type and value of goods and facilities bought over the Internet (Partnership, 2005, p. 15). Data disaggregated by gender are virtually non-existent. The reasons for this dearth of data are a lack of awareness among policymakers of the value of statistics and limited resources and competences to gather and accumulate these data [24]. Nonetheless, existing research on e-commerce/ e-retailing allows us to recognize significant patterns. Early studies on B2B e-commerce [25]; [26] have claimed that e-commerce, particularly e-retailing, will only be effective if the trust and confidence involved in business dealings, such as payment security and quality control of the purchased product, and governments are able to create the corresponding regulatory and legal framework to make customers and manufacturers feel secure when via the Internet [27].

\subsection{Best Practices in E-Commerce/E-Retailing in Business Industries}

We categorize our best practices into training and enablement of women, expanding market access and generating profit-making opportunities, government and institutional support, societal involvement, and appropriate managerial practices, based on the insights from our literature review. Under training and empowerment of women, we identify ICT and business-related training, externalities produced by successful developments and the moral cycle of economic individuality and enablement as key drivers. ICTs and e-commerce/e-retailing also simplify better and wider market access, better information, and elimination of the distributer, completely impacting the cost structure. Our study shows that ecommerce/e-retailing projects which emphasis on excellence, status and product variation are also more fruitful. It is vital to note that given the intrinsic biases against women-run enterprises in many societies, these qualities become particularly significant for such women-owned trades. Managements and supporting organizations have an imperative role to play in providing the early impetus and ongoing support for effective projects as they often provide both the necessary structure and also are a huge part of the women owned business' customer base. Family support is very crucial, particularly for women with minor children. It is very difficult to manage both home and business duties without family support. Lastly, sound administrative performances such as a strong obligation to outstanding in the business. Furthermore, decent corporate status and respectable public relations are mostly key achievement issues for women-owned e-commerce/e-retailing trades. Training and empowerment of woman can enhance the E-Commerce/E-Retailing in business industries.

We have analyzed numerous research such as the Village Pay Phones (VPPs) in Bangladesh; ICT training camp in village, internet café in rural city; computer training center; all point to the difficult leads plays the success role of ICT-based project undertake by woman.

\subsection{Expanding Market Access and Generating Profit Making Opportunities}

Additional significant determinant of achievement as demonstrated in case studies such as Tortas Peru, Women Weavers in Morocco, CI-GM, Computer Facility at Kasargod, Kerala, India and Divine Computers of Vadakara, India was expanding market access to portable business opportunities.

\subsection{Government and Institutional Support Monitoring and Evaluation}

Case studies such as the Computer Facility at Kasargod, Kerala, India, and e-Seva Centres in Andhra Pradesh, India, also highlight the important role of institutions and government in providing the initial impetus and the ongoing momentum for these ICT-based projects. 


\subsection{Social Involvement}

The significant part that the provision of the resident culture plays is highlighted in case studies such as the Computer Capacity at Kasargod, Kerala, India; e-Seva Centres in Andhra Pradesh, India; Women Weavers of Morocco; and Rupununi Weavers Project, Guyana.

\subsection{Managerial Best Practices}

All of the case studies highlight the significance of sound executive practices as important determinants of successful e-commerce ventures. The key managerial best practices are discussed below.

1. A participatory and open management style is a vital issue in the achievement of women-owned ecommerce projects. Peer group provision and guidance, from both women and men, are valuable in overcoming challenges and realizing achievement. Associates at the Kasargod capability specified that their unity was a key issue in their accomplishment.

2. Venture in primary and additional training is key to providing high excellence products and facility and serving the staff cover tasks during each other's nonappearances.

3. Respectable community relations in the native community, with the management activities and with clients aided gather new commercial and simplified development.

4. All the positive developments showed a strong promise on the part of the women to stay the sequence and prosper despite several social, economic and other difficulties.

\section{Conclusion}

The foremost area of this paper was to progress a set of best performances in the parts of ICTs and the authorization of women finished e-commerce/e-retailing. We started with an evaluation of the current theoretic literature regarding the main factors influencing the success of ICT-based e-commerce/eretailing projects for women. In light of the theoretical framework, we then examined specific case studies to understand how well theory relates with the real-world realisms of women-owned ecommerce/e-retailing schemes, and to grow a set of best performances.

\section{Reference}

1. Bhatnagar, S., \& Schware, R. (2000). Information and communication technology in development. New Delhi/Thousand Oaks, CA/London: Sage Publications.

2. Friedman, E.J. (2005). The reality of virtual reality: The Internet and gender equality advocacy. Latin American Politics and Society, 47(3), 1-34.

3. Hafkin, N., \& Huyer, S. (Eds.) (2006). Cinderella or cyberella? Empowering women in the knowledge society. Bloom ${ }^{\text {a }}$ eld, CT: Kumarian Press.

4. World Bank. (2006). Engendering ICT Toolkit. Retrieved July 29, 2016, from http:// go.worldbank.org/1KSAAHFPMO.

5. Lafond, R., \& Sinha, C. (Eds.). (2005). E-commerce in the Asian context. Selected case studies. Ottawa: International Development Centre and Singapore: Institute of Southeast Asian Studies.

6. Sciadas, G. (2005). From digital divides to digital opportunities: Measuring Infostates for development. Ottawa: Orbicom and Claude-Yves Charron.

7. Karake-Shalhoub, Z., \& Qasimi, A. (2007). The Diffusion of E-commerce in Developing Economies: A Resource Based Approach. Cheltenham, UK: Edward Elgar Publishing.

8. Eggleston, K., Jensen, R. T., \& Zeckhauser, R. (2002). Information and communication technologies, markets and economic development. In G. Kirkman, P. K. Cornelius, J. D. Sachs, \& K. Schwab (Eds.), The global information technology report 2001-2002. Readiness for the Networked World (pp. 62-74). Oxford: Oxford University Press.

9. Kelkar, G., \& Nathan, D. (2002). Gender relations and technological change in Asia. Current Sociology, 50(3), 427-441. 
10.Drucker, P. (2001). Quoted in Arun, S. and Arun, T. (2002) "ICTs, Gender and Development: Women in Software Production in Kerala," Journal of International Development 14(1), 39-50, p. 40.

11.Hafkin, N., \& Taggert, N. (2001). Gender, technology, and developing countries: An analytic study. Washington, DC: USAID Of ${ }^{\mathrm{a}}$ ce of Women in Development.

12.Hafkin, N. (2002). Get in and get in early: Ensuring women's access to and participation in ICT projects.

Women in Action 2. Special issue on Women and Communications. Isis-Manila.

http:// www.isiswomen.org/pub/wia/wia202/getin.htm

13.Huyer, S. (2005). Women, ICT and the Information Society: Global Perspecties and Initiatives. ACM International Conference Proceeding Series; Vol. 12, Proceedings of the International Symposium on Women and ICT: Creating Global Transformation.Baltimore.

14.Huyer, S., \& Mitter, S. (2003). ICTs, globalisation and poverty reduction: Gender dimensions of the knowledge society.

15.Rice, M.F. (2003). Information and communication technologies and the global digital divide: Technology transfer, development and least developing countries. Comparative Technology Transfer and Society, 1(1), 72-88.

16.Kenny, C. (2002). Information and communication technologies for direct poverty alleviation: Costs and bene ${ }^{\mathrm{a}}$ ts. Development policy review, 20(2), 141-157.

17.Nath, V. (2006). "Empowerment of Women through ICT-enabled Networks: Towards the Optimum ICT-impact Model," in N. Hafkin \& S. Huyer (eds.), Cinderella or Cyberella: Empowering Women in the Knowledge Society, Bloom ${ }^{a}$ eld, CT: Kumarian Press

18.Sen, A. (2000). Development as freedom. New York: Anchor Books.

19.Garrido, M., \& Roman, R. (2006). Women in Latin America. Appropriating ICTs for social change. In N. Hafkin \& S. Huyer (Eds.), Cinderella or Cyberella? Empowering Women in the Knowledge Society. Bloom ${ }^{\mathrm{a}}$ eld, CT: Kumarian Press.

20.Poster, W., \& Salime, Z. (2002). "The Limits of Microcredit: Transnational Feminism and USAID Activities in the United States and Morocco." In N. Naples and M. Desai (Eds.), Women's Activism and Globalization: Linking Local Struggles and Transnational Politics. New York: Routledge. pp. 189-218.

21.Hafkin, N., \& Huyer, S. (Eds.) (2006). Cinderella or cyberella? Empowering women in the knowledge society. Bloom ${ }^{a}$ eld, CT: Kumarian Press.

22.Morgan, S., Heeks, R., \& Arun, S. (2004). Research ICT-based enterprise for women in developing countries: A gender perspective. Retrieved November 2, 2006, from http:// www.womenictenterprise.org/ GenderResearch.doc

23.Hafkin, N., \& Taggert, N. (2001). Gender, technology, and developing countries: An analytic study. Washington, DC: USAID Of ${ }^{a}$ ce of Women in Development.

24.United Nations Conference on Trade and Development (UNCTAD). (2004). E-commerce and development. New York and Geneva: United Nations.

25.Goldstein, A., \& O'Connor, D. (2000). E-Commerce for development: Prospects and policy issues. Paris: OECD Development Centre.

26. Organisation for Economic Co-operation and Development (OECD). (1997). Electronic commerce: Opportunities and challenges for government.

27.Joseph, L., \& Narayanan, S. (2005). E-Marketers: An innovative approach to e-commerce. In R. Lafond \& C. Sinha (Eds.), E-Commerce in the Asian context. Selected case studies (pp. 49-69). Ottawa: International Development Centre and Singapore: Institute of Southeast Asian Studies. 